\title{
Early Stage Testicular Seminoma: A Multicenter Review of Treatment Outcomes and Patterns of Recurrence
}

\author{
M. Kim \\ University of Pennsylvania \\ E. Wuthrick \\ Thomas Jefferson University and Hospitals
}

A. Lin

University of Pennsylvania

Follow this and additional works at: https://jdc.jefferson.edu/bodinejournal

Part of the Oncology Commons

Let us know how access to this document benefits you

\section{Recommended Citation}

Kim, M.; Wuthrick, E.; and Lin, A. (2010) "Early Stage Testicular Seminoma: A Multicenter Review of Treatment Outcomes and Patterns of Recurrence," Bodine Journal: Vol. 3 : Iss. 1 , Article 35.

DOI: https://doi.org/10.29046/TBJ.003.1.034

Available at: https://jdc.jefferson.edu/bodinejournal/vol3/iss1/35

This Article is brought to you for free and open access by the Jefferson Digital Commons. The Jefferson Digital Commons is a service of Thomas Jefferson University's Center for Teaching and Learning (CTL). The Commons is a showcase for Jefferson books and journals, peer-reviewed scholarly publications, unique historical collections from the University archives, and teaching tools. The Jefferson Digital Commons allows researchers and interested readers anywhere in the world to learn about and keep up to date with Jefferson scholarship. This article has been accepted for inclusion in Bodine Journal by an authorized administrator of the Jefferson Digital Commons. For more information, please contact: JeffersonDigitalCommons@jefferson.edu. 


\title{
Early Stage Testicular Seminoma: A Multicenter Review of Treatment Outcomes and Patterns of Recurrence
}

\author{
Kim. M., ${ }^{1}$ Wuthrick, E., ${ }^{2}$ Lin, A. ${ }^{1}$ \\ 1Department of Radiation Oncology, University of Pennsylvania, Philadelphia, PA \\ 2Department of Radiation Oncology, Thomas Jefferson University and Hospitals, Philadelphia, PA
}

\section{Purpose/Objective(s)}

Although overall survival for early stage testicular seminoma is generally excellent, certain pathologic factors can increase recurrence risk for those undergoing observation, while radiation therapy (RT) can be associated with long-term morbidity. We sought to identify disease-related and treatment-related factors that influenced the outcomes, with particular emphasis on recurrence risk, patterns and timing of recurrence, as well as RT-induced malignancy.

\section{Material/Methods}

With IRB approval, we identified and reviewed medical records of stage I or II testicular seminoma patients from two institutions (University of Pennsylvania and Thomas Jefferson University) who received adjuvant RT or observation between 1979-2009. Patient-, disease-, and treatment-related variables were obtained including age, history of undescended testicle, previous inguinal surgery, date of diagnosis, stage, tumor volume and characteristics, RT dose/ fractionation and volume, disease recurrence, and second malignancy.

\section{Results}

A total of 104 patients were identified: 92 with stage I disease and 12 with stage II disease. Median age was 37 years and median follow-up was 3.2 years. Eighty-one stage I patients underwent adjuvant RT ( $88 \%$ of study population), while 11 underwent observation (12\% of study population). All stage II patients were treated with adjuvant RT. Total RT dose ranged from 9-36 Gy (median $=26 \mathrm{~Gy}$ ). Five patients (4 stage I, 1 stage II) experienced disease recurrence at a median of 1.7 years ( $4.8 \%$ of study population). Among stage I patients with recurrence, 2 patients received RT (2.5\% of treated population), while 2 patients were observed (18\% of observed population). Local control with adjuvant RT was $100 \%$, as all recurrences were systemic, outside of the RT field. Disease-related factors, such as largest tumor dimension, tumor size, lymphovascular invasion, rete testis and spermatic cord involvement, and preoperative laboratory markers (LDH, B-HCG) were not found to be significantly associated with recurrence risk. Three patients developed a second malignancy within the RT field (3.3\% of treated population) at a median time of 14.6 years. All 3 patients were treated with dogleg field to a median dose of $36 \mathrm{~Gy}$.

\section{Conclusion}

Although early stage seminoma is associated with excellent longterm results, our study suggests recurrence risk approaches $20 \%$ in patients undergoing observation. Routine follow-up regimens should be adhered to, especially in the first few years, as most recurrences occurred within 2 years of treatment. While rates of RT-induced malignancy were low, these rates may be further improved by minimizing RT dose and volume. 